\title{
SOME NEOCENE CORALS OF THE UNITED STATES.
}

\author{
By Henry Stewart Gane, Ph. D., \\ Fellow in Geology, Johns Hopkins University, 1894-95.
}

\section{INTRODUCTION.}

At the suggestion of Prof. William B. Clark, of the Johns Hopkins University, the writer was encouraged to undertake the study and systematic description of the Neocene corals of the United States. Furthermore, the present paper has been constructed both as to method of treatment and arrangement of subject-matter upon the general plan of Professor Clark's bulletin on the Mesozoic Echinodermata of this country.

No attempt had been made hitherto to treat this subject from the present standpoint, the few corals previously described being offered to science either as possessing only zoological interest, or else to complete a local fauna.

The first mention of a Neocene coral from this country is found in the Petrefacta Germaniæ of Goldfuss (1829), where Madrepora palmata is both described and figured. During the thirty years following this first description there were at irregular intervals a number of scattered contributions to the subject. The more important were those of T. A. Conrad, W. Lonsdale from the collections made by Sir Charles Lyell, and Milne-Edwards and Jules Haime. More recently there have been but two papers worthy of notice, one in 1887 by Prof. P. M. Duncan on the genus Septastrcea d'Orbigny, from the Miocene of Maryland, and one in 1888 by Dr. G. J. Hinde as a criticism of Professor Duncan's article. It is of interest to note that the researches of Dr. Hinde on this $\Lambda$ merican species are almost unprecedented, no similar coral having been treated in so exhaustive a manner. In considering all the references we notice the somewhat remarkable fact that by far the most important writings have appeared both in foreign journals and from the pens of foreign paleontologists.

The material treated has been loaned to the writer from the collections of the U. S. National Museum, Wagner Free Institute of 
Science, the Philadelphia Academy of Sciences, the private cabinet of Mr. Joseph Willcox, of Philadelphia, and the Johns Hopkins University. The state of preservation of the forms is as a rule excellent, with the exception of the silicified corals from Florida. These latter are often very difficult of determination, owing to prefossil wear and the mineralogical change the specimens have since undergone. Frequently the poorly preserved calices alone remain, the entire inside of the individual or the colony being dissolved away and represented by a cavity with walls of botryoidal character. When the original substance of the coral, with the exception of the outer surface, is thus replaced, it becomes impossible, as an aid to identification, to cut sections showing the coral structure below the calice. The cause and method of silification of these corals has never been satisfactorily proven. Professor Heilprin, ${ }^{1}$ in discussing the phenomena in his treatise on the Explorations on the West Coast of Florida, attributes the change to an infiltration of silica in a heated condition, but adds that he can not even hazard a guess, much less explain in what precise manner the peculiar method of hollowing was brought about. Especially is this true of the colonial types with botryoidal-shaped cavities. Furthermore, in the genera possessed of very small calices, as in Porites and Stylophora, their delicate structure is often so destroyed as to render a specific diagnosis impossible.

The writer has also been at a great disadvantage from the fact that a number of the species have been described from single specimens, and until further collecting is done in the field it will be impossible to give a more detailed specific description of these forms.

The fauna under discussion embraces in its geological distribution, the Neocene and Oligocene epochs. On the other hand, geographically the range of these forms is remarkably confined. With the single exception of a few casts from the Miocene of Griswoldville, Fresno County, California, we find them limited to the Atlantic seaboard States, from New Jersey to Florida, inclusive.

In considering this fauna as a unit, its most striking feature is the great number and variety of the genera represented as compared with the species, there being twenty-eight of the former to thirty-five of the latter. This proportion of genera to species is quite unusual, the number of species in any given fauna more often being far in excess of the genera. As an instance, we may cite the present fauna of Bermuda, with its twenty-eight species to only ten genera, or the results reported by the Challenger, which during its entire cruise obtained only sixty-nine genera of reef corals to two hundred and ninety-three species, and many of these presenting considerable variaation. We find, further, in taking account of the Neocene corals, that the colonial far outnumbers the individual type.

In examining the bathymetric distribution of the species, it is doubt- 
ful whether any truly deep-sea forms are represented. The few genera that might be so classed are also frequently found living in shallow depths. When we add to the above the fact that they occur in the deposits side by side with true reef builders, we may consider that the corals living in the ()ligocene and Pliocene periods flourished as shallow. water forms with preponderating reef-building teudencies.

Both from their kind and the relations which the coral genera and species of a particular area bear to one another, it is possible to judge of the similarity or of the variation of the physical conditious prevail. ing in the region.

Regarding this hypothesis, Prof. P. M. Duncan, ${ }^{1}$ in his first article on the West Indian fossil corals, says :

The range, in strata, of the genera of corals is often so great, and the species of remote formations are so frequently closely allied; that the Zoantharia form better guides for estimating the external physical circumstances of the regions in which they existed than for determining the age of the strata. There are fow subjects better understood than the relation between the presence of certain genera and species of coral and certain definite, external physical conditions. Depth of sea, purity of sea water, its intense aeration, force of wave, absence of fresh water, the climate and nature of the coast line, with all their possible varieties, appear to determine, according to their mutual reactions, the presence and persistence of species and genera. Indeed, very slight variations from the general rule of the external circumstances in a coral sea would appear to prevent the derelopment of certain genera. It is a reasonable induction that, if a species be found in strata of any age and distant in space, the two sets of strata were formed under the same external physical circumstances.

If this be true, then the conditions prevailing upon the Atlantic coast during Neocene time were most varied, both from a geological and a geographical standpoint; for we find that in the fauna under discussion the genera of the corals are quite varied, and that the individual species are very limited, both vertically and horizontally, in their stratigraphic distribution. In this distribution the Pliocene species are perhaps more liable to be limited in their geographical range than in their geological, since a number of the forms are either found as recent or having closely related living allies, whereas the Miocene species appear to be about equally confined both from a geographical and a geological aspect.

A majority of the corals represented belong to extinct species. few are now found living in the Caribbean Sea, and some belong to closely allied fossil forms from santo Domingo and other West Indian islands.

We should expect that the Neocene corals of the United States would have close kinship with those of like age in the West Indies, but such does not seem to be generally the case. On the other hand, according to Professor Duncan the fossil Oligocene corals of the West Indies are closely related to those of the Miocene of Europe aid the recent faunas of the Pacific and Indian oceans. Regarding the affinities of the Neo- 
cene fauna of the United States as a whole, we come to the conclusion that it has more of a likeness to that at present living in the Caribbean Sea and Atlantic Ocean than to the fauna, recent or fossil, of any other region.

The descriptions of families and genera will not be repeated in the present work, as they are to be found in the paper of Prof. P. Martin Duncan on "A Revision of the Families and Genera of the Scleroder. mic Zoantharia, Edwards and Haime, or Madreporaria ( $M$. rugosa excepted)," which also contains the system of classification employed in the present memoir.

The author wishes to express his thanks, througi Mr. William H. Dall and Mr. Joseph Willcox, to the Wagner Free Institute of Science for the loan of many of the specimens herein described; also to $\mathrm{Mr}$. $\mathrm{T}$. Wayland Vaughan for much kindly assistance and advice. Mr. Vaughan has looked over the paper after it was written and has attended to having the figures drawn.

\section{BIBLIOGRAPHY.}

1826-1833. Goldfuss, A. Petrefacta Germaniæ.

1834. Ehrenberg, C. G. Beiträge zur physiologischen Kenntniss der Corallenthiere im Allgemeinen, und besonders des rothen Meeres, nebst einem Versuch zur physiologischen Systematik derselben. Abhand. Akad. Wiss. Berlin, pp. $225-380$.

1834. De Blainvlle, H. M. D. Manuel d'actinologie ou de zoophytologie.

1835. Conrad, T. A. Observations on a portion of the Atlantic Tertiary region. Trans. Geol. Soc. Penn., I, Pt. 2, pp. 335-341, pl. XIII.

1836. De Lamarck, J. B.P. A. Histoire naturelledes animaux sans vertèbres. 2 ded. II, Histoire des Polypes. With notes by G. P. Deshayes and H. MilneEdwards.

1837. Rogers, W. B. and H. D. Contributions to the geology of the Tertiary Formations of Virginia. Trans. Am. Phil. Soc., new ser., V, p. 319.

1841. Conrad, T. A. Descriptinns of twenty-six new species of fossil shells discovered in the Medial Tertiary deposit of Calvert Cliffs, Maryland. Proc. Acad. Nat. Sci. Philadelphia, I, pp. 28-33.

1842. Conrad, T. A. Descriptions of twenty-four new species of fossil shells, chiefly from the Tertiary deposits of Calvert Cliffs, Maryland. Jour. Acad. Nat. Sci. Philadelphia, 1st ser., VIII, pp. 183-190.

1845. Lyell, C. On the Miocene Tertiary strata of Maryland, Virginia, and of North ard South Carolina. Quart. Jour. Geol. Soc. London, I, pp. 413-429.

Lonsdale, W. Account of ten species of Polyparia obtained from the Miocene Tertiary formations of North America. Quart. Jour. Geol. Soc. London, I, pp. 495-509, 10 wood-cuts.

1846. Conrad, T. A. Observations on the Eocene formation of the United States, with description of species of shells, etc., occurring in it. [At end of article see] Note; being remarks on Lonsdale's species. Am. Jour. Sci., 2d ser., I, pp. 209-221.

Dana, J. D. Remarks on Corals (appendix to an article on Eocene fossils of United States, by T. A. Conrad). Am. Jour. Sci., 2d ser., I, pp. 220, 221.

DANA, J.D. U. S. Exploring Expedition. Zoophytes.

1847. Lonsdale, W. Remarks on the Character of several Species of Tertiary Corals from the United States, in reply to Mr. Dana. (Extracted from a letter from W. Lonsdale to C. Lyell, esq.) Am. Jour. Sei., 2d ser., IV, p. 357. 
1847. Dana, J. D. Observations in reply to Mr. Lonsdale's Remarks. Am. Jour. Sci., 2d ser., IV, pp. 359-362.

1818. Tuомey, M. Report on the Geology of South Carolina.

BronN, H. G. Index Palæontologicus.

1849. D'Orbigny, A. Note sur les Polypiers fossiles.

Milne-Edwards, H., and Jules Haime. Recherches sur les Polypiers. Ann. des Sci. Nat., 3d ser., XLI, pp. 95-197.

Milne-Edwards, H., and Jules Haime. Mémoire sur les Polypiers appartenants à la famille des Oculindes, au groupe intermédiaire des Pseudastréides et à la famille des Fongides. Comptes Rendus, XXIX, pp. 67-73.

1850. Milne-Edwards, H., and Jules Haime. Recherches sur les Polypiers. Ann. des Sci. Nat., 3d ser., XIII, pp. 63-110.

Milne-Edwards, H., and Jules Haime. British Fossil Corals, Palæontographical Society.

1851. Milne-Edwards, H., and Jules Haime. Monographie des Polypiers Fossils des Terrains Palæozoiques, precedée d'un Tableau General de la Classification des Polypes. Archiv. Mus. Hist. Nat., V.

1850-1852. D'Orbigny, A. Prodrome de Palæontologie stratigraphique universelle des Animaux Mollusques et Rayonnés.

1853-1856. Bronn, H. G. Lethea Geognostica.

Tuomey, M., and Holmes, F. S. Plieocene Fossils of South Carolina.

1857. Milne-Edwards, H., and Jules Haime. Histoire Naturelle des Coralliaires. 1858. Emmons, E. Report on North Carolina Geological Survey, Agriculture of the Eastern Counties, and Description of Fossils of the Marl Beds.

1860. Holmes, F. S. Post Pliocene Fossils of South Carolina.

1861. Fromentel, E. D. Introduction a l'etude des polypiers fossiles.

1864. Меек, F. B. Check List of Invertebrate Fossils of North American Miocene.

1868. Verrill, A. E. Review of the Corals and Polyps of the West Coast of America. Trans. Conn. Ac. Art. Sci., I, Pt. 2, p. 377.

1884. Rogers, W. B. and H. D. Contributions to the Geology of the Tertiary Formations of Virginia in a "Reprint of Annual Reports and other papers on the Geology of the Virginias." New York.

1886. Duncan, P. M. (Abstract of paper) On a new Genus of Madreporaria Glyphastræa, with remarks on the Glyphastræa Forbesi, Edwards and Haime, sp. from the Tertiaries of Maryland, U. S. Abstract Proc. Geol. Soc. London, No. 495.

1887. Duncan, P. M. On a new Genus of Madreporaria-Glyphastræa, with remarks on the Glyphastræa Forbesi, Edwards and Haime, sp. from the Tertiaries of Maryland, U. S. Quart. Jour. Geol. Soc. London, XLIII, p. 24, pl. III.

1887. Heillprin, A. The Miocene Mollusca of the State of New Jersey. Proc. Acad. Nat. Sci. Philadelphia, XXXIX, pp. 397-405.

1888. Hinde, G. J. On the History and Characters of the Genus Septastræa, D'Orbigny (1849), and the Identity of its Type Species with that of Glyphastræa, Duncan (1887). Quart. Jour. Geol. Soc. London, XLIV, p. 200, pl. IX.

1895. Gane, H. S. A contribution to the Neocene Corals of the United States. Johns Hopkins Univ. Circulars, XV, No. 121, October, pp. 8-10. 


\section{Class ANTHOZOA.}

Suborder ZOANTHARIA SCLERODERMATA (or MADREPORARIA).

Section MADREPORARIA APOROSA.

Family TURBINOLID $\nRightarrow$ (part) Edwards and Haime.

Genus DESMOPHYLLUM Ehrenberg.

DESMOPHYLLUM WILLCOXI Gane.

(Plate XV, figs. 1-3.)

1895. Desmophyllum willcoxi GaNe, Johns Hopkins Univ. Circ., XV, No. 12, October, 1895 , p. 9.

Corallum quite variable in shape, more or less compressed, conical, attached at base by a moderately long pedicle, which may be either broad or narrow. Surface of the wall and costal ridges smooth, at times showing the development of an epitheca. Costæ well developed, corresponding to all septa, more prominent near the calicular margin, margins not acute, some granulations over the surface. The summits of the calice in the shorter diameter are higher than in the longer. The margin of the calice is irregularly dentate. The interior of the wall coarsely pitted here and there between the septa. There are six systems of septa with four well-developed cycles, and a fifth rudimentary. The septa are exsert, rather stout, thicker near the wall and in the vicinity of the base of the calicular fossa; they are generally straight but often curved, with granulated sides, and the surface often shows quite distinct striations. In well-preserved specimens the fossa is deep and narrow, and the free margins of the septa at the base of the fossa often form by means of small rod-like projections a sort of columella as in Flabellum.

Such a pseudocolumella similar to that found in the present species is described by Mr. H. N. Mosely " in his report on the "Deep Sea Madreporaria" as occurring in the Desmophyllum ingens from the fjords of western Patagonia.

This species is respectfully dedicated to Mr. Joseph Willeox, of Philadelphia.

Dimensions.-The dimensions of the largest specimen are: Height, 28 $\mathrm{mm}$.; greatest length and least width of calice, respectively, 32 and $25 \mathrm{~mm}$. The calices of the majority of the specimens are, however, more compressed than in this one.

Geological horizon.-Upper Oligocene.

Locality._Ballast Point, Tampa Bay, Florida.

Collections.-Wagner Free Institute of Science, and in the private cabinet of Mr. Joseph Willcox, of Philadelphia.

${ }^{1}$ Challenger Expedition, Zoology, II, Pt. 7. Report on certain Hydroid, Alcyonarian, and Madreporarian corals procured during the voyage of H. M. S. Challenyer, in the years $1873-1876$, p. 161. 
Genus PARACYATHUS Edwards and Haime.

\section{PARACYATHUS VAUGHANI Gane.}

$$
\text { (Plate XV, figs. 4-6.) }
$$

1895. Paracyathus vaughani GANE, Johns Hopkins Univ. Circ., XV, No. 121, October. 1895 , p. 9.

Corallum small, broad and low, with the calice about the same diameter as the base, above which the wall is somewhat constricted. Wall thin, eostulate to its base. Costre low, unequal, finely granular, more prominent near the calicular margin where they are considerably thicker than their corresponding septa. Calice circular in the young, slightly oval in the adult individual; fossa broad, moderately deep. Septa in six systems of five cycles lacking part of the sixth order of the last cycle; in forms of medium size, only four cycles are present. Primaries and secondaries subequal, thick and stout, with summits more broadly rounded and more strongly exsert than those of the remaining thin and slender septa; sides coarsely granulated, edges of the higher eycles regularly crenately dentate. Pali granular, present before all the septa but those of the last cycle, excepting in the most mature forms, where they may be lacking before a part of the fourth as well as before all of the fifth cycle of septa. Columella papillose, well developed.

In polishing down the base of the coral, the rings marking the existence of previous outer walls are clearly seen. In one specimen no less than eight appear, showing the growth of the coral and its relation to the development of its septa.

The individuals of this form generally occur alone attached to some shell, but occasionally they are found in clusters, being in close contact with one another at their sides or the outer edge of their bases.

Dimensions.-Height of largest specimen, $4 \mathrm{~mm}$.; breadth of calice, $11 \mathrm{~mm}$.

Geological horizon-Miocene, Chesapeake formation.

Lócality.-Carters Landing, James River, and Yorktown, Virginia.

Collections.-U. S. National Museum (type); Wagner Free Institute of Science; Johns Hopkins University.

\section{Family OCULINID A (part) Edwards and Haime. \\ Genus ASTROHELIA Edwards and Haime.}

\section{ASTROHELIA PALMATA (Goldfuss).}

1826-1833. Madrepora palmata Goldfuss, Petrefacta Germaniæ, Pt. 1, p.23, pl. xxx, figs. $6, a, b$.

1834. Oculina palmata Ehrenberg, Abhand. Berlin, Ak. Wiss. for 1832 , pp. 305, 344. 1834. Madrepora palmata Blainville, Man. Act. ou Zooph., p. 390.

1836. Madrepora palmata Lamarck, Hist. Nat. Animaux sans Vert., 2d ed., II, p. 450. 1848. Oeulina palmata Bronn, Index Palæontologicus, I, p. 835.

1849. Astrhelia palmata Edwards and HaIme, Compte Rendus Ac. Sci., XXIX, p. 68. 
1850. Astrhelia palmata Edwards and Harme, British Fossil Corals, Introd., p. 20. 1850. Astrhelia palmata Edwards and HaIme, Ann. des Nat., 3d ser., XIIII, p. 74.

1851. Astrhelia palmata Edwards and Haime, Archiv. Mus. Hist. Nat. Paris, V, p. 37. 1853-1856. Astrhelia palmata Bronn, Lethaæ Geognostica, Pt.6, p. 307.

1857. Astrohelia palmata Edwards and HaIme, Hist. Nat. des Corall., II, p. 111. 1864. Astrohelia palmata Мекк, Check-list Invert. Foss. N. Am. Miocene, p. 1. 1895. Astrohelia palmata GANE, Johns Hopkins Univ. Circ., XV, No. 121, p. 9.

Colony forming a palmate mass with more or less coalescing branches. In specimens which are not water worn the costæ are quite distinct at the calicular edge and bent, passing at times into slight flattened ridges on the surface of the coenenchyma. Calices slightly unequal and separated by irregular distances from one another, moderately deep, and projecting somewhat above the coenenchyma. Septa in two cycles of about equal size, with a third cycle, generally rudimentary, at times, however, fully developed; narrow, coarsely toothed with granular sides. The septa often unite in the center forming a small somewhat spongy columella.

This cural is of interest as being the first described from the Neocene of this country.

Dimensions.-Breadth of calice from 2 to $3 \mathrm{~mm}$.

Geological horizon.-Miocene, Chesapeake formation.

Locality.-Shiloh, New Jersey, and common at many localities in Maryland.

Collections.--U. S. National Museum; Philadelphia Academy of Natural Sciences; Wagner Free Institute of Science; Johns Hopkins University.

\section{Family AS'TR EID E Edwards and Haime, amended. Genus CIRCOPHYLLIA Edwards and Haime.}

Subgenus ANTILLIA Duncan.

\section{ANTILliA GUESDESI (Duchassaing and Michelotti).}

1850. Turbinolia biloba Duchassanvg, Anim. Rad. des Antilles, p. 14 (not Michelin).

1854. (?) Circophyllia, species 3, Lonsdale, manuscript.

1861. Montlivaultia guesdesii Duchassaing and Michelotti, Mem. Acad. Sci. Torino, XIX, p. 345 , pl. v, fig. 13.

1864. Antillia bilobata Duncan, Quart. Jour. Geol. Soc., XX, p. 31, pl. iII, fig. 3.

1866. Antillia guesdesii Duchassaing and Michelotti, Mem. Acad. Sci. Torino, XXIII, p. 172.

1868. Antillia bilobata DunCan, Quart. Jour. Geol. Soc., XXIV, p. 23.

1870. Antillia guesdesii Duchassaing, Revue des Zooph. et des Spong. des Antilles, p. 29.

1875. Antillia bilobata Pourtalès, Geol. Mag., new ser., 2d Dec., II.

1895. Antillia biloba GaNe, Johns Hopkins Univ. Circ., XV, No. 121, p. 9.

Corallum simple, nearly straight, conical, at times constricted vertically so as to appear more or less bilobate, pedicellate. Epitheca well developed and membraniform. Costæ large above, projecting outward $2.5 \mathrm{~mm}$. from the calicular margins; edges rounded and marked by tubercles; sides granulated at their upper extremites in radiating rows extending over from the septa. Exotheca frequently present between 
the costæ, inclined, and forming cells. In the largest specimens the calicular area is somewhat less than that of a transverse section of the coral about $15 \mathrm{~mm}$. below the margins. Calice variable in shape from quiteoval to compressed, sometimes constricted centrally, approximating in shape the figure eight; it is shallow and presents a wavy margin on a nearly even plane in the adult, uneven in the young. The fossa is deep and narrow. There are six systems with five complete cycles of septa, and in the adult individuals sometimes several orders of a sixth. The septa are crowded, often curved, a little thicker at the wall than elsewhere, marked on their upper edges with a very slight serration of small papillæ; the sides have radiating rows of granules which merge with those on the costæ; this regularity of granular arrangement is not so marked in the vicinity of the lower part of the fossa. Columella long, dense, and spongy. Endotheca abundant.

When comparing the coral at different stages in its growth, this species is very variable in shape. In the young forms, we find the corallum more conical than turbinate, more strongly attached, and its calice much more oval and not at all resembling the figure eight in outline. The margin of the calice is more sinuous, with the longer axis more depressed than the shorter. Epitheca less prominent. Septa in only four cycles, straighter and less crowded. Fossa deeper than in the adult form.

The number of specimens examined by the writer is numerous, representing quite a series of individuals of most varied size and shape. Had either of several extreme types occurred alone without the connecting forms it might well be considered as a distinct species.

The young are but slightly, if at all, bilobed, the most matured individuals alone being turbinate and vertically constricted with a figure eight shaped calice, the latter characteristics being described by Professor Duncan as typical of the West Indian forms.

Dimensions.-The dimensions of the largest specimens are: Height, 50 mm.; greatest length and least width of calice, respectively, 59 and 25 $\mathrm{mm}$. When comparing the above measurements with those of the largest specimens from Santo Domingo, the latter are found to be far larger in size than the forms occurring in Florida.

Geological horizon.-Upper Oligocene, Chipola formation.

Locality.-Bailey's Ferry, Chipola River, Calhoun County, Florida; Santo Domingo, Guadeloupe (horizon not given), West Indies.

Collection.-U. S. National Museum.

Genus ASTRANGIA Edwards and Haime.

ASTRANGIA LINEATA (Conrad).

1835. Lithodendron lineatus Conrad, Trans. Geol. Soc. Pa., I, Pt. 2, p. 340, pl. xiII, fig. 4.

1845. Anthophyllum lineatum LyeLL, Quart. Jour. Geol. Soc., I, p. 424.

184.5. Anthophyllum lineatum Lonsdale, Quart. Jour. Geol. Soc., I, p. 495, fig. a.

1845. Caryophyllia lineata ConRad (Manuscript label), Quart. Jour. Geol. Soc., I, p. 495 . 
1846. Lithodendrum lineatum CONRAD, Am. Jour. Sci., 2d ser., I, p. 220.

1848. Anthophyllum lineatum Bronn, Index Palæontologicus, I, p. 83.

1864. Cladocora? lineata MeEK, Check-list Invert. Foss. N. Am. Miocene, p. I

1895. Astrangia lineata GANe, Johns Hopkins Univ. Cire., XV, No. 121, p. 9.

Colony encrusting, consisting of conical or cylindrical corallites, the largest sometimes rising a centimeter above the surface of the loas:il expansion. Individual corallites divergent, but usually touching at their bases. Walls very thin at their calicular edge, thicker below. Epitheca extremely thin, finely granulated and in some forms slowing parallel, somewhat sinuous, flat and broad striæ extending to the base. True costæ of unequal size are at times present in the vicinity of the calicular edge. Calice as a rule circular, at times considerably compressed, deep. Septa much narrowed at the top, in mature forms in four complete cycles; septa of the last cycle much thinner and narrower than those of the preceding, often merely rudimentary; in the younger individuals septa but thirty-six; there is a tendency for the younger septa to turn toward and unite with the older; inner edges strongly dentate, teeth slightly coarser near the columella; sides granulated, though not stoutly so. Columella small and formed of a net-work of trabiculæ with additions from the septal ends. Multiplication by budding chiefly from basal expansions, although it may take place well up on the side of a parent corallite.

The writer refers this species to the genus Astrangia, although there is more of an epitheca present than has been hitherto considered as characteristic of the genus. In all other respects this species seems to be typical. Lonsdale, in his description of the coral, states that it closely resembles the Lithodendron flexuosum described by Michelin in his Iconographie Zoolphytogique, from the faluns of Touraine, but Edwards and Haime have since pronounced the species of Michelin to be a Cladocora. As this American species lacks pali and possesses neither a shallow calice nor septa quite exsert, it can not belong to the genus Cladocora.

Dimensions.-Breadth of calice, from 4 to $8 \mathrm{~mm}$.

Geological horizon.-Miocene, Chesapeake formation.

Locality.-Bellefield, Yorktown, Carters Landing, and City Poirí, Virginia.

Collections.-U. S. National Museum; Philadelphia Academy of Natural Sciences; Wagner Free Institute of Science; Johus Hopkins University.

\section{ASTRANGIA ASTR EIFORMIS Edwards and Haime.}

1850. Astrangia astraiformis EDWARDS and HaIme, Ann. des Sc. Nat., 3d ser., XII, p. 181.

1857. Astrangia astraiformis Edwards and HaIme, Hist. Nat. des Coralliaries, II, p. 614.

1863. Astrangia astrceiformis Verrill, Mem. Boston, Soc. Nat. Hist., I, p. 39.

1871. Astrangia astraiformis Pourtalès, Ill. Cat. Mus. Comp. Zool. Harvard Coll., No. IV, p. 80.

1895. Astrangia astraiformis GaNe, Johns Hopkins Univ. Circ, XV, No. 121, p. 9. 
Colony encrusting, of closely united corallites often free at their summit. Walls minutely granulated on the exterior surface. Costre present, most distinct near the calicular edge. Calices open, deep and circular except when crowded. Septa very slightly exsert, narrowed at top, in six systems of three complete cycles with part of a fourth; those of the third cycle a little narrower than the preceding, uniting with them inferiorly and near the columella; edges sharply and somewhat coarsely dentate; sides granulated. Columella well developed, papillary, the outer part resembling the inner teeth of the septa. Gemmation both from marginal buds on the basal expansion and from the sides of the coral between the parent corallites.

This species is found recent on the shores of the Atlantic from North Carolina to Florida. It is very nearly related to Astrangia dance Agassiz, occurring on the coast of this country from New Jersey to Massachusetts. It also in many respects resembles the fossil Astrangia lineata from the Virginia Miocene.

Dimensions.-Breadth of calice, from 2 to $4 \mathrm{~mm}$.

Geological horizon.-Miocene.

Locality.-Cain Hoy, South Carolina.

Collections.-U. S. National Museum.

Genus ASTRANGIA Edwards and Haime.

Subgenus COENANGIA Verrill.

CENANGIA BELLA (Conrad).

1841. Astra bella Conrad, Proc. Ac. Nat. Sci. Phila., I, p. 33.

1842. Astrce bella Conrad, Jour. Ac. Nat. Sci. Phila., VIII, Pt. 2, p. 189.

1857. Astrangia? bella Edwards and Haime, Hist. Nat. des Corall., II, p. 615.

1857. Astrac bella Tuomey and Holmes, Pleiocene Foss. South Carolina, p. 1, pl. I, figs. 1, 1 .

1860. Astrcea bella Holmes, Pleiocene Foss. South Carolina, p. 1, pl. I, fig. 2.

1861. Astrangia? bella DE Fromentel, Introduct. Polyp. Foss., p. 237.

1864. Astraa bella Меeк, Check-list Invert. Foss. N. Am. Miocene, p. 1.

1868. Astrangia (Cenangia) bella Verrill, Trans. Conn. Ac. Art. Sci., I, Pt. 2, p. 530. 1895. Cœnangia bella Gane, Johns Hopkins Univ. Cire., XV, No. 121, p. 9.

Colony incrusting, rising at times into lobate extensions. Corallites thin walled, closely united. Calices irregularly prismatic, quite deep, with their fossæ narrow at the bottom. Septa in three complete cycles, the third less stout and usually curved toward and united, near the columella, to those of the preceding cycle; occasionally part of a fourth cycle is developed. Septa thin, with free edges sharply and roughly denticulated throughout; sides somewhat coarsely granulated, frequently the granules being also present on the inside wall of the calice. Columella moderately developed, spongy, composed of contorted processes originating from the inner margins of the septa. Gemmation takes place in the interspaces between the corallites.

This species is closely related to the living Conangia conferta of the Pacific, and Astrangia dance Agassiz and Astrangia astraiformis of the Atlantic. 
Dimensions.-Breadth of calice, from 3 to $6 \mathrm{~mm}$.

Geological horizon.--Miocene, Chesapeake formation; and (Pleiocene? of Tuomey and Holmes).

Locality.--Darlington, South Carolina; Newbern, North Carolina; Prince George County, Virginia.

Collections.--U.S. National Museum.

\section{CENANGIA MARYLANDICA (Conrad).}

1841. Astraa marylandica Conrad, Proc. Ac. Nat. Sci. Phila., I, p. 33.

1842. Astrcea marylandica Conrad, Jour. Ac. Nat. Sci. Phila., ViII, Pt. 2, p. 189.

1845. Astraa hirtolamellata? LyelL, Quart. Jour. Geol. Soc., I, p. 424.

1845. Astraa hirtolamellata Lonsdale, Quart. Jour. Geol. Soc., I, p. 500, fig. 1.

1846. Astraa marylandica Conkad, Am. Jour. Sci., 2d ser., I, p. 220.

1846. Astroitis or Pleiaäia marylandica DANA, Am. Jour. Sci., 2d ser., I, p. 221.

1847. Astraca marylandica Lonsdale, Am. Jour. Sci., 2d ser., IV, p. 359.

1847. (Allied to Caryophyllia family) DaNa, Am. Jour. Sci., 2d ser., IV, p. 361.

1848. Astraa marylandica Tuomey, Report Geol. South Carolina, pp. 182, 208.

1848. Dipsastraea hirtolamellata Brons, Index Palæontologicus, I, p. 126.

1857. Astraa marylandica Tuomey and Holmes, Pleiocene Foss. South Carolina, p. 2, pl. I, figs. 2, $2 a$.

1857. Astrangia? marylandica Edwards and Haime, Hist. Nat. des Corall., II, p. 615. 1864. Astraa marylandica Мекк, Check-list Invert. Foss. N. Am. Miocene, p. 1.

1868. Astrangia (Cœnangia) marylandica Verrill, Trans. Conn. Ac. Art. Sci., I, Pt. 2, p. 550.

1895. Conangia marylandica Gane, Johns Hopkins Univ. Circ., XV, No. 121, p. 9.

Colony incrusting, at times rising into lobes in the middle. Corallites in close contact but the individual walls distinct. Calices crowded, irregular in size and shape, oval, circular, and polygonal, the latter predominating, moderately deep, with perpendicular walls. Interseptal chambers very wide. Septa subequal in two cycles, thin, the free edge subentire and concave; uniting at their inner margins to form a pseudocolumella. Walls and septa of the calices completely covered with minute tubercles. Dissepiments scarce. Growth of corallum by budding of young corallites from between the angles of the older cells.

This species is common in the Miocene bluffs of the James River, Virginia, where it is generally found incrusting the surface of the Pecten jeffersonius.

In the opinion of the writer this apparently distantly related coral will, upon further study, prove to have close affinities with the Septastraca sexradiata of Lonsdale.

The nearest living ally to this form, according to Professor Verrill, is the Conangia conferta of the Pacific Ocean. The latter, however, differs from the fossil coral in possessing usually 24 septa and only moderately wide interseptal chambers; the walls are thinner; the septa have larger lateral granules, and the columella is more strongly developed. Professor Verrill further adds ${ }^{1}$ "that the close relation of this living (Pacific Ocean) species to the fossil and recent species (Astrangia dance and Astrangia astraiformis) of the temperate coasts on the Atlantic

Notes on Radiata, Trans. Conn. Acad. Arts and Sci., I, Pt. 2, p. 531. 
side, together with the occurrence of certain shells that are apparently identical in the two regions, but found neither in the arctic nor in the tropical regions, is very suggestive of a former connection, perhaps in early tertiary times, between the two oceans, through the temperate parts of North America."

Dimensions.-Breadth of calice, from 2 to $4 \mathrm{~mm}$.

Geological horizon.-Miocene, Chesapeake formation and (Pleiocene ? of Tuomey and Holmes).

Locality.-Virginia and South Carolina.

Collections.-U. S. National Museum; Philadelphia Academy of Natural Sciences; Wagner Free Institute of Science; Johns Hopkins University.

Subgenus PHYLLANGIA Edwards and Haime.

PHYLLANGIA FLORIDANA Gane.

(Plate XV, figs. 7-9.)

1895. Phyllangia floridana GANE, Johns Hopkins Univ. Circ., XV, No. 121, p. 9.

Colony encrusting, consisting of subturbinate corallites arising from the basal expansion. Individuals generally free above but somewhat closely united at their base. Walls thin at the calicular edge, thicker below. Costæ low, subequal, minutely granulated, reaching to the base, but more prominent at the calicular margin and at the swellings just beneath the constrictions in the walls of the corallites. About on a level with the bottom of the fossa, the diameter of the corallite is least, the walls being here somewhat constricted, beneath which constriction they are again frequently swelled to a diameter equal to that at the calicular margin. Calices somewhat expanded, widely open, deep, narrow at the bottom. Septa crowded, in six systems of four complete cycles, lacking a few septa of the fifth order; primaries and secondaries more exsert, thicker and broader than the septa of the following cycles, quarternaries least exsert, thinnest and narrowest; sides of the septa sharply granulated and the edges of all but the fourth cycle rounded superiorly and subentire in their upper parts, the lower two-thirds of the septal edges being strongly lobate or dentate, the uppermost tooth being the most prominent and similar in shape to a true paliform lobe. Columella papillary occupying a very limited area; the line of separation between the papillæ of the columella and the lowest teeth of the septa being indistinguishable. Gemmation by budding from the basal expansion of the wall of a parent corallite.

This form in its general size and mode of growth very much resembles the Astranqia lineata (Conrad) of the Virginia Miocene deposits.

Dimensions.-Breadth of calice, from 4 to $6 \mathrm{~mm}$.

Geological horizon.-Pliocene, Caloosahatchie beds.

Locality._Alligator Creek, Monroe ('ounty, Florida.

Collections.-U. S. National Musenm. The type specimen was collected by Mr. Joseph Willcox, of Philadelphia. 
Genus CLADOCORA Edwards and Haime.

CLADOCORA JOHNSONI Gane.

(Plate XV, figs. 10-12.)

1895. Cladocora johnsoni Gane, Johns Hopkins Univ. Circ., XV, No. 121, p. 10.

Corallites slender, somewhat flexuous, and cylindrical. When found fossil they are detached from the parent colony. Walls of moderate thickness. Costæ granular, well developed, and close set; those corresponding in position to the septa of the first and second cycles of the same size, and larger than those corresponding the members of the third and fourth cycles. With the exception of a few costæ of the fourth cycle, all reach to the base of the corallite. Calices circular with a shallow fossa. There are six systems of three complete cycles, with occasionally a few rudimentary. septa of an incompleted order of a fourth cycle. Septa exsert, the primaries more prominently so, rounded and very finely granulated laterally, giving the laminæ a slightly striated appearance; primaries thicker and broader than secondaries, which, in turn, have a similar relation to the tertiaries. In sections of a corallite below the calice, the septa of the third cycle approach and midway between the theca and columella unite with those of the preceding cycle. Either true pali or paliform lobes are present before all but the last cycle of septa. Columella coarsely papillary but rather narrow. Gemmation lateral and often in pairs at the same height on the stem.

The nearest related form to this Pliocene coral seems to be the Cladocora debilis Edwards and Haime, recent at Maderia, but owing to its meager descriptions the writer can not speak definitely on this point, as he has not had an opportunity of examining specimens of the species.

The present form is named after Mr. Charles W. Johnson, of Philadelphia, who has added so much to our knowledge of the Neocene paleontology of the South.

Dimensions.-Height of the largest specimen, $12 \mathrm{~mm}$; breadth of calice, from 2 to 2.8 .

Geological horizon.-Pliocene.

Locality.-Waccamaw River, South Carolina.

Collections.-Wagner Free Institute of Science (type), Johns Hopkins University. The type specimens were collected by Mr. C. W. Johnson.

Genus MANICINA Ehrenberg.

MANICINA PLIOCENICA Gane.

1895. Manicina pliocenica Gane, Johns Hopkins Univ. Circ., XV, No. 121, p. 10.

Colony very variable in shape, with a sinuous outline, from compressed conical to subhemispherical; attached by a slender pedicle, the lower part of the base curved in the direction of the greater axis of the 
colony. Valleys rather wide, long and deep, having perfect communication between them. Corallines broad and furrowed. Wall thin. Epitheca well developed, pellicular; its lines of growth in wavy ridges of varied thickness, the thinnest of which are pierced by the granules of the costr; in some cases it is limited to the lower part of the base, in others it reaches to the summit of the outer wall of the colony. Costæ of nearly equal size, the oldest only reaching the pedicle; considerably exsert, being a continuation of the septa at their upper edges; finely toothed on the free edge, rows of granules on the sides. Exotheca abundant. Septa quite exsert, slightly thicker at the wall, granulated laterally in radiating rows, with free edge regularly toothed, the teeth being somewhat larger near the paliform lobe, which is somewhat thicker, at least near the columella, than the principal septum to which it belongs. Columella well developed, narrow, of a coarse spongy nature, especially when seen in vertical section. Endotheca abundant, with dissepiments of unequal length inclined toward the inner and lower edges of the septa.

Pourtalès ${ }^{1}$ considered that all the living West Indian types of this genus represented one species, the Manicina areolata (Linnæus). Whether this be true or not, the species under discussion differs from all recorded living forms. More especially it varies from Manicina areolata in the following particulars: Its collines are generally broader; the septo-costæ of adjoining individuals are rarely united, the walls of the individuals being distinct; septa somewhat stouter and less crowded together, in very rare cases only exceeding eleven in number to the centimeter; the teeth on the inner edge of the septa are more regular in size and shape. On the other hand, in Manicina areolata the collines are narrow, with many of the septo-costæ of neighboring individuals united. The septa are thinner and more crowded, from fifteen to twenty (Quelch) to the centimeter. The teeth on the inner edge vary more in different parts of the same septum. This differentiation of the teeth on different parts of the edge of the septum and paliform lobe, as shown by the living types, is well illustrated in the "Report on the Florida Reefs" by Agassiz. ${ }^{2}$

Dimensions. - This species is very variable in size and shape. The greatest width of one corallum measured is $100 \mathrm{~mm}$.; length, $150 \mathrm{~mm}$. (estimated); height, $80 \mathrm{~mm}$.; of another, width, $55 \mathrm{~mm}$; length, 135 $\mathrm{mm}$. ; height, $55 \mathrm{~mm}$.

Geological horizon.-Pliocene.

Locality.-Caloosahatchie River, Florida.

Collections.-U. S. National Museum (type), collected by Mr. W. H. Dall; Wagner Free Institute of Science, collected by Messrs. Heilprin and Willcox.

${ }^{1}$ Ill. Cat. Mus. Comp. Zool., Harvard Coll., No. IV, pp. 72, 73.

Memoir Mus. Comp. Zool., Harvard Coll., VII, No. 1, pl. vi, fig. 6.

Proc. N. M. vol. xxii- -13 
Genus SEPTASTRAA d'Opbigny (1849), emend. Hinde.

SEPTASTR㞋A SEXRADIATA (Lonsdale).

1837. Astrea sp. W. B. and H. D. Rogers, Trans. Am. Phila. Soc., new ser., V, p. 338. 1845. Columnaria? sexradiata Lonsdale, Quart. Jour. Geol. Soc., I, p. 497, figs. $a, b$. 1845. Columnaria? sexradiata L yell, Quart. Jour. Geol. Soc., I, p. 416.

1846. Astroitis sexradiata Dana, Am. Jour. Sci., 2d ser., I, p. 221.

1846. Astroitis sexradiata Dana, U. S. Exploring Expedition, Zoophytes, p. 722.

1848. Columnaria? sexradiata Brons, Index Palæontologicus, I, p. 321.

1849. Septastrcea forbesi Edwards and HaIme, Ann. des Sci. Nat., 3d ser., XII, p. 64. 1849. Septastraa subramosa D'Orbigny (nominal), Note sur les Polyp. foss., p. 9.

1852. Septastráa subramosa D'Orbigny, Prodir. de Pal., III, p. 146.

1857. Septastraca forbesi Edwards and Hamme, Hist. Nat. des Corall., II, p. 450.

1857. Astrangia? bella Edwards and Haime, Hist. Nat. des Corall., II, p. 615.

1861. Astrangia? bella DE Fromentel, Introduction Polyp. foss., p. 237.

1861. Septastraa forbesi DE Fromenter, Introduction Polyp. foss., p. 174.

1851. Septastraca forbesi Edwards and Harme, Archiv. Mus. Nat. Hist., V, p. 115.

1864. Septastraa? sexradiata Мекк, Check-list Invert. Foss., N. Am. Miocene, p. 1. 1864. Septastraa forbesi МеEк, Check-list Invert Foss. N. Am. Miocene, p. 1.

1884. Astrea eq. W. B. and H. D. Rogers, Reprint of Ann. Reports and other Papers on Geology of the Virginias, p. 667.

1886. Glyphastraa forbesi Duncan, Abstract. Proc. Geol. Soc. London, No. 495, p. 18. 1887. Glyphastrcea sexradiata Duncan, Quart. Jour. Geol. Soc., XLIII, p. 30.

1887. Glyphastraa forbesi DUnCAN, Quart. Jour. Geol. Soc., XLIII, p. 29, pl. III.

1888. Septastraa sexradiata Hinde, Quart. Jour. Geol. Soc., XLIV, p. 219, pl. ix, figs. 6-16.

1888. Septastrca forbesi Hinde, Quart. Jour. Geol. Soc., XLIV, p. 218, pl. IX, figs. $1-5,7-15,17$.

1895. Septastraa sexradiata GaNe, Johns Hopkins Univ. Circ., XV, No. 121, p. 10.

Colony incrusting at base, rising into cylindrical compressed stems with short, rounded branches or of large flattened masses with lobate and digitiform expansions. Corallites with walls in close contact but distinct one from another, subcylindrical in the interior, although prismatic at the surface of the corallum. The matured calices are shallow with thickened margins, an impressed line generally marking the division between the individuals; the floors of the calices, which have a dome-shaped elevation in the center, are entirely closed with stereoplasm, the upper edges of the septa alone slightly projecting. When the calices are immature or much crowded the walls are thin and the floor near its periphery is incomplete. The entire calice when perfectly preserved is covered with minute tubercles, although the surface of the septa in the interior of the corallites is smooth. Septa usually 12 in the lower portion of the corallite; in the calice a rudimentary third cycle is often added. Abnormally the calice may possess from 0 to 36 septa. The inner septal ends are often intertwisted to form a pseudocolumella. Dissepiments very thin, irregularly developed, frequently at the same level in the different interseptal loculi, usually from 1 to $2 \mathrm{~mm}$. apart, the uppermost dissepiment of the corallite forming the base to the infilling stereoplasm. Increase by gemmation from buds formed at the interspaces between the walls of adjarent mature corallites. 
For a further detailed and most elaborate description of this coral consult the paper by Dr. G. J. Hinde on the genus Septastrca in general, and the present species in particular. Nothing but the mode of attachment is now added to the characteristies of the form as so clearly determined by Dr. Hinde.

The present writer, however, considers the Septastraca forbesi Edwards and Haime, as a synonym of the S. sexradiata Lonsdale. In discussing the similiarity of the two species Dr. Hinde ${ }^{1}$ aptly summarizes the subject in the following words. He says that-

It is very evident that in form, mode of growth, and in every other feature but one, this species (S. sexradiata) is closely similar to Septastraa forbesi. The one feature in which it differs is the greater development of the third cycle of septa within the calices. This feature, curiously enough, is limited to the calices, for in the lower part of the corallites only the 12 septa of the first and second cycles are developerl, as in S. forbesi, so that specimens in which the surface features are partially obliterated can not be distingnished from this latter species. I have serious doubts whether this one feature may not, after all, be due to a more favorable condition of growth or environment to which this particular specimen has been exposed. It is somewhat remarkable that of the thirteen specimens of Septastraa which have come under my notice this is the only one which exhibits such a development of the third cycle of septa in the calices; in all others this cycle is only indicated by marginal ridges. There is a considerable amount of variation in this respect in the specimens referred to Septastrca forbesi, for in some only 6 septa are developed in the calices, in others 12 , and yet no specific distinction can be made, since in certain specimens both conditions are present. It might therefore be urged that, as Lonsdale's specimen is undistinguishable in every other respect from Septastra forbesi, the difference in this variable feature does not possess specific value. While admitting the force of the argument, I think it is preferable provisionally to allow the difference to be specific, and if further evidence should show that it must be regarded as merely due to external conditions, and that there is only one species, then this species must bear Lonsdale's name of sexradiata, since this has the priority of Edwards and Haime's name, forbesi.

As the form under discussion is the most common coral occurring in the beds of the Virginia Miocene, the writer has had an opportunity of studying a large series of specimens, and has reached the conclusion as stated above that all belong to the same species, although in the superficial calices there is often a remarkable divergence in the relative development of the septa and the pseudocolumella. Were the Septastraa forbesi allowed of specific value, then a number of new specific names should be employed for these forms with calices, either containing but 6 or less septa, or with the septa of the latter cycles united with those of the preceding, or with the other similar modifications in the calice.

That both Mr. Lonsdale and Sir Charles Lyell considered these Septastrce as of one species, the S. sexradiata is evinced by the fact that the former, who described the forms, gave but one specific name to them, and the latter, who collected the specimens, stated ${ }^{2}$ that lying on the beach of the James River were masses of the S. sexradiata upward of

'Quart. Journ. Geol. Soc., XLIV, p. 220.

${ }^{2}$ Idem., I, 1845 p. 416. 
2 feet in width, which had been washed out of the shell marl. The above would show that both Lonsdale and Lyell regarded the coral described as representing the specimens collected rather than of a peculiar variety as has been since considered by later writers, with the possible exception of Dr. Hinde, who desired further information on the subject before finally committing himself.

The first reference to this coral is found in 1837 as a footnote to an article $^{1}$ on the geology of the Tertiary formations of Virginia by W. B. and $H$. D. Rogers. They remark that an Astrea of immense magnitude was lying at that time half buried in sand on the beach of Tarbay, James River, having fallen to its present position from an overhanging cliff. They add further that it was much reduced in size since its fall, but had then an approximate weight of 700 pounds and a diameter in its greatest length of $4 \frac{1}{2}$ feet. Mr. Arthur Bibbins has recently secured this historic specimen for the Geological Museum of the Woman's College of Baltimore where it is now preserved.

Dimensions.-The largest specimen is about 1.5 meters in its greatest diameter; breadth of calices from 3 to $8.5 \mathrm{~mm}$. with an average width of $4.6 \mathrm{~mm}$.

Geological horizon.-Miocene, Chesapeake formation.

Locality.-Bellefield and Yorktown on the York River, and at many points on the James River, Virginia. In some of the previous papers on the subject this coral is frequently mentioned as coming from Maryland, but none of the specimens in the collections examined by the writer came from that State.

Collections.-U.S. National Museum; Philadelphia Academy of Natural Sciences; Wagner Free Institute of Science; Johns Hopkins University; Woman's College of Baltimore.

CATALOGUE OF SPECIFIC NAMES EMPLOYED BY WRITERS UPON THE NEOCENE CORALS OF THE UNITED STATES.

Anthophyllum lineatum Lonsdale, 1845, Astrangia lineata (Conrad) ......... $\quad{ }^{187}$

lineatum Lyell, 1845, Astrangia lineata (Conrad)............ 187

lineatum Bronn, 1848, Astrangia lineata (Conrad)............ 188

Antillia biloba (Duchassaing) Gane 1895 ............................. 186

bilobata Duncan, 1864, Antillia biloba (Duchassaing).............. 186

bilobata Duncan, 1868, Antillia biloba (Duchassaing) ............... 186

bilobata Pourtalès, 1875, Antillia biloba (Duchassaing)............. 186 guesdesii Duchassaing and Michelotti, 1866, Antillia biloba (Duchas-

saing) ..................................................... 186

Astra a bella Tuomey, 1857, Conangia bella (Conrad) $\ldots . . . . . . . . . . . . . . .2189$

bella Holmes, 1860, Coenangia bella (Conrad) .................... 189

marylandica Conrad, 1846, Conangia marylandica (Conrad) ........... 190

marylandica Lonsdale, 1847, Coenangia marylandica (Conrad) ......... 190

marylandica Tuomey and Holmes, 1857, Conangia marylandica (Con-

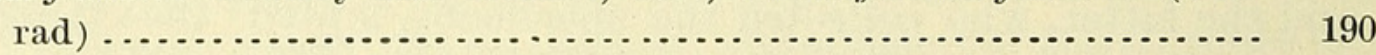

marylandica Meek, 1864, Conangia marylandica (Conrad) ............ 190

1 Trans. Am. Phil: Soc., new ser., V, p. 338, or in the Reprint of the Geology of the Virginias, p. 667. 
Astrangia astraiformis Edwards and Haime, 1850, Gane, 1895 . . . . . . . . . . astraiformis Edwards and Haime, $1857 \ldots \ldots \ldots \ldots \ldots \ldots \ldots \ldots . \ldots \ldots$ astraiformis Verrill, 1863, Astrangia astraiformis Edwards and Haime . $\quad 188$ astraiformis Pourtalès, 1871, Astrangia astraiformis Edwards and

Haime........................................

? bella Edwards and Haime, 1857, Conangia bella (Conrad) ........

\& bella Edwards and Haime, 1857, Septastroxa sexradiata (Lonsdale).

\& bella de Fromentel, 1861, Conangia bella (Conrad) ...............

\& bella de Fromentel, 1861, Septastraca sexradiata (Lonsdale).......

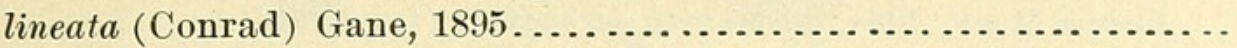

\& marylandica Edwards and Haime, Conangia marylandica (Conrad)

Astrea sp. Rogers, W. B. and H. D., 1837, Septastraca sexradiata (Lonsdale)... sp. Rogers, W. B. and H. D., 1884, Septastraxa sexradiata (Lonsdale)...

Astrae bella Conrad, 1841, Conangia bella (Comrad) ..................... bella Conrad, 1842, Conangia bella (Conrad) ....................

bella Meek, 1864, Conangia bella (Conrad) .......................

hirtolamellata? Lyell, 1845, Conangia marylandica (Conrad) .......... hirtolamellata Lonsdale, 1845, Cœnangia marylandica (Conrad) ........ marylandica Conrad, 1841, Conangia marylandica (Conrad) .......... marylandica Conrad, 1842, Conangia marylandica (Conrad) ........... mavylandica Tuomey, 1848, Conangia marylandica (Conrad) ..........

Circophyllia species 3, Lonsdale, manuscript, 1854, Antillia guesdesi (Duchassaing

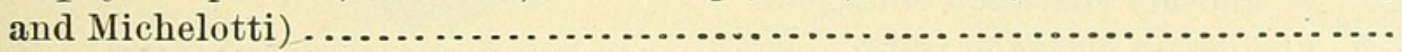

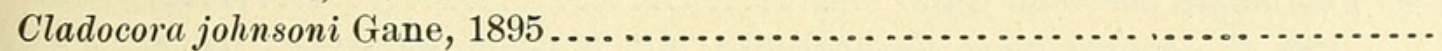

? lineata Meek, 1864, Astrangia lineata (Conrad) .................. Conangia bella Verrill, 1868, Conangia bella (Conrad) ..................

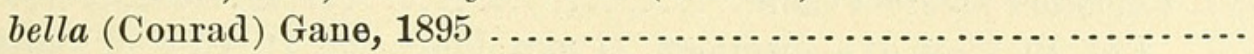
marylandica Verrill, 1868, Conangia marylandica (Conrad).........

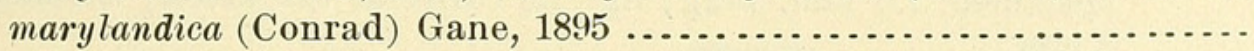
Columnaria? sexradiata Lonsdale, 1845, Septastrae sexradiata (Lonsdale)...... sexradiata Lyell, 1845, Septastraca sexradiata (Lonsdale) ......... sexradiata Bronn, 1848, Septastraca sexradiata (Lonsdale).........

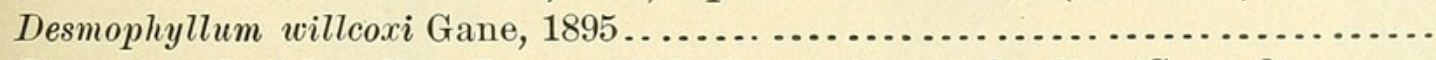
Dipsastraa hirtolamellata Bronn, 1848, Conangia marylandica (Conrad)........ Glyphastraa forbesi Duncan, 1886, Septastraa sexradiata (Lonsdale) .......... sexradiata Duncan, 1887, Septastraca sexradiata (Lonsdale) ........

forbesi Duncan, 1887, Septastrax semadiata (Lonsdale) . .........

Lithodendron lineatus Conrad, 1835, Astrangia lineata (Conrad) ..............

lineatum Cónrad, 1846, Astrangia lineata (Conrad)............. 
Oculina palmata Ehrenberg, 1834, Astrohelia palmata (Goldfuss)............. 185 palmata Bronn, 1848, Astrohelia palmata (Goldfuss) ............... 185

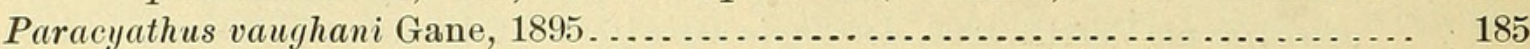

Phyllangia floridana Gane, 1895 . . . . . . . . . . . . . . . . . . . . . . . . . . . . . 191

Pleiadia or Astroitis marylandica Dane, 1846, Conangia marylandica (Conrad).. 190

Septastrac forbesi Edwards and Haime, 1849, Septastraa sexradiata (Lonsdale) . 194

forbesi Edwards and Haime, 1851, Septastraa sexradiata (Lonsdale)... 194

forbesi Edwards and Haime, 1857, Septastraa sexradiata (Lonsdale).. . 194

forbesi de Fromental, 1861, Septastraa sexradiata (Lonsdale) ....... 194

forbesi Meek, 1864, Septastraa sexradiata (Lonsdale)............. 194

forbesi Hinde, 1888, Septastraa sexradiata (Lonsdale) . . . . . . . . . . . 194

? sexradiata Meek, 1864, Septastraa sexradiata (Lonsdale) . . . . . . . 194

sexradiata Hinde, 1888, Septastraa sexradiata (Lonsdale) ......... 194

sexradiata (Lonsdale) Gane, 1895 . . . . . . . . . . . . . . . . . . . . . . 194

subramssa d'Orbigny, 1849, Septastrcea sexradiata (Lonsdale) ...... 194

subramosa d'Orbigny, 1852, Septastraa sexradiata (Lonsdale) ...... 194

Turbinolia biloba Duchasisaing, 1850, Antillia guesdesi (Duchassaing and Miche-

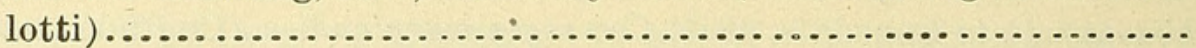

\section{EXPLANATION OF PLATE.}

Plate XV.

Figs. 1-3. Desmophyllum willcoxi Gane..............................

Fig. 1, view of a specimen from the side; altitude of specimen, $28 \mathrm{~mm}$; f fig. 2, calice of the same, greater diameter, $32 \mathrm{~mm}$; fig. 3 , view of another specimen, looking at end of longer transverse axis, altitude of specimen, $30 \mathrm{~mm}$.

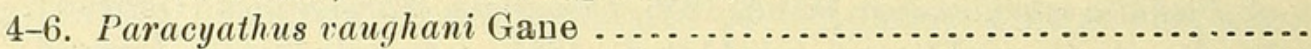

Fig. 4, view of a specimen from the side, altitude, $6 \mathrm{~mm}$.; fig. 5 , calice of the same, greater diameter, $8 \mathrm{~mm}$; fig. 6 , costæ of another specimen enlarged.

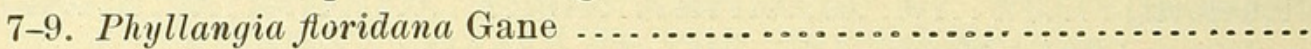

Fig. 7, general view, natural size; fig. 8, costæ enlarged; fig. 9, a calice, greater diameter, $6.5 \mathrm{~mm}$.

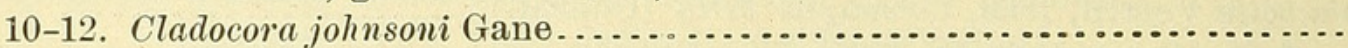

Fig. 10, view of a specimen, $11 \mathrm{~mm}$. long; fig. 11, view of anoth specimen, $7.5 \mathrm{~mm}$. long; fig. 12, calice of the latter, diameter, $3 \mathrm{~mm}$. 


\section{$2 \mathrm{BHL}$ Biodiversity Heritage Library}

Gane, Henry Stewart. 1900. "Some Neocene corals of the United States." Proceedings of the United States National Museum 22(1193), 179-198.

https://doi.org/10.5479/si.00963801.22-1193.179.

View This Item Online: https://www.biodiversitylibrary.org/item/99942

DOI: https://doi.org/10.5479/si.00963801.22-1193.179

Permalink: https://www.biodiversitylibrary.org/partpdf/70378

\section{Holding Institution}

Smithsonian Libraries

\section{Sponsored by}

Biodiversity Heritage Library

\section{Copyright \& Reuse}

Copyright Status: Public domain. The BHL considers that this work is no longer under copyright protection.

This document was created from content at the Biodiversity Heritage Library, the world's largest open access digital library for biodiversity literature and archives. Visit BHL at https://www.biodiversitylibrary.org. 